\title{
The Fossil-Lagerstätte Enspel — a crater lake in a volcanic- influenced terrestrial environment of the Westerwald Basin (late Oligocene, Western Germany)
}

\author{
Michael Wuttke • Thomas Schindler • Krister T. Smith
}

Received: 8 December 2014 / Accepted: 9 December 2014 / Published online: 10 February 2015

(C) Senckenberg Gesellschaft für Naturforschung and Springer-Verlag Berlin Heidelberg 2015

The Westerwald region belongs to the Central European Volcanic Province (CEVP). As seen here, the Westerwald Basin is an aggregation of small basins (the smallest ones cover an area as little as $10,000 \mathrm{~m}^{2}$ ), mainly situated within the Variscan Mosel, Lahn and Dill Synclines. Sedimentation started in the middle Eocene (Hottenrott 2002). A pre-existing landscape was filled first by coarse sediments, followed by clays and brown coal (Schäfer et al. 2011). Tectonic activity seems to have increased during the middle late Oligocene, resulting in an increasing relief, displayed by sandy sediments (Butz and Vortisch 1987). Two watersheds separate the Westerwald Basin from the Lower Rhine Embayment (Schindler and Wuttke 2013) (Fig. 1).

In the late Oligocene, volcanic activity commenced with trachytic intrusions, phreatomagmatic maar eruptions (Enspel) and pyroclastic eruptions. They were followed by basic shallow intrusions, lava flows, and continued maar formation (Elbtal, ?Elz) and the deposition of thick pyroclastics (Schreiber 1996; Haase et al. 2004). Locally, the eruptions and minor intercalated sediments covered the landscape up to $50 \mathrm{~m}$ high (Schäfer et al. 2011).

This article is a contribution to the special issue "The Fossil-Lagerstätte Enspel - reconstructing the palaeoenvironment with new data on fossils and geology"

\section{Wuttke $(\bowtie) \cdot$ T. Schindler}

Direktion Landesarchäologie, Referat Erdgeschichte,

Generaldirektion Kulturelles Erbe Rheinland-Pfalz,

Große Langgasse 29, 55116 Mainz, Germany

e-mail: michael.wuttke@gdke.rlp.de

\section{K. T. Smith}

Department of Palaeoanthropology and Messel Research,

Senckenberg Research Institute, Senckenberganlage 25,

60325 Frankfurt am Main, Germany
Reischmann (2011) relates the Oligocene volcanism to the Alpine orogeny and North Atlantic rifting; the main reason is extension and thinning of the lithosphere, resulting in a passive uplift of the asthenosphere; partial melting was caused by pressure release, which resulted in the eruptions in the CEVP.

The volcanic activity led to changes in the local drainage systems, e.g. dammed valleys with subsequent lake formation. Caused by contemporaneous temporarily high Chattian sea level, palustrine facies became widespread, so that thick lignite seams were formed along with laminated lake sediments (e.g. Lake Norken, Uhl et al. 2011; fossil site Breitscheid, Schindler and Kolb 2010). Hygrophilous plant communities covered the lowlands. The macroflora of this riparian vegetation is dominated by leaves of Acer cf. tricuspidatum BRONN, twigs of Glyptostrobus europaeus (BRONGNIART) UNGER and charcoalified wood of Cupressaceae (Taxodiaceae s.1.), as seen in the lacustrine to swampy sediments of Lake Norken (Uhl et al. 2011).

Upland or dryland floras and faunas were also influenced by volcanic activity. Forests died under heavy ash load, and their remnants were washed into the lowlands and partly preserved as silicified trunks. Isolated reptile and mammal bones and teeth (e.g. Teike and Tobien 1950) can be found within coarse volcanic ash (personal field observation, and unprepared material of the collections of the Museums of Breitscheid, Hachenburg, Wiesbaden and the Hessisches Landesamt für Umwelt und Geologie, Wiesbaden, all Germany), demonstrating the influence of pyroclastic and/or lahar events on the biota. Floral recovery starts with pioneering plants like Cyperaceae, Poaceae and Betulaceae. This pioneering flora was succeeded by zonal assemblages of a mesophytic forest with strong East Asian influence (Herrmann et al. 2003, 2010; Köhler and Uhl 2014). 


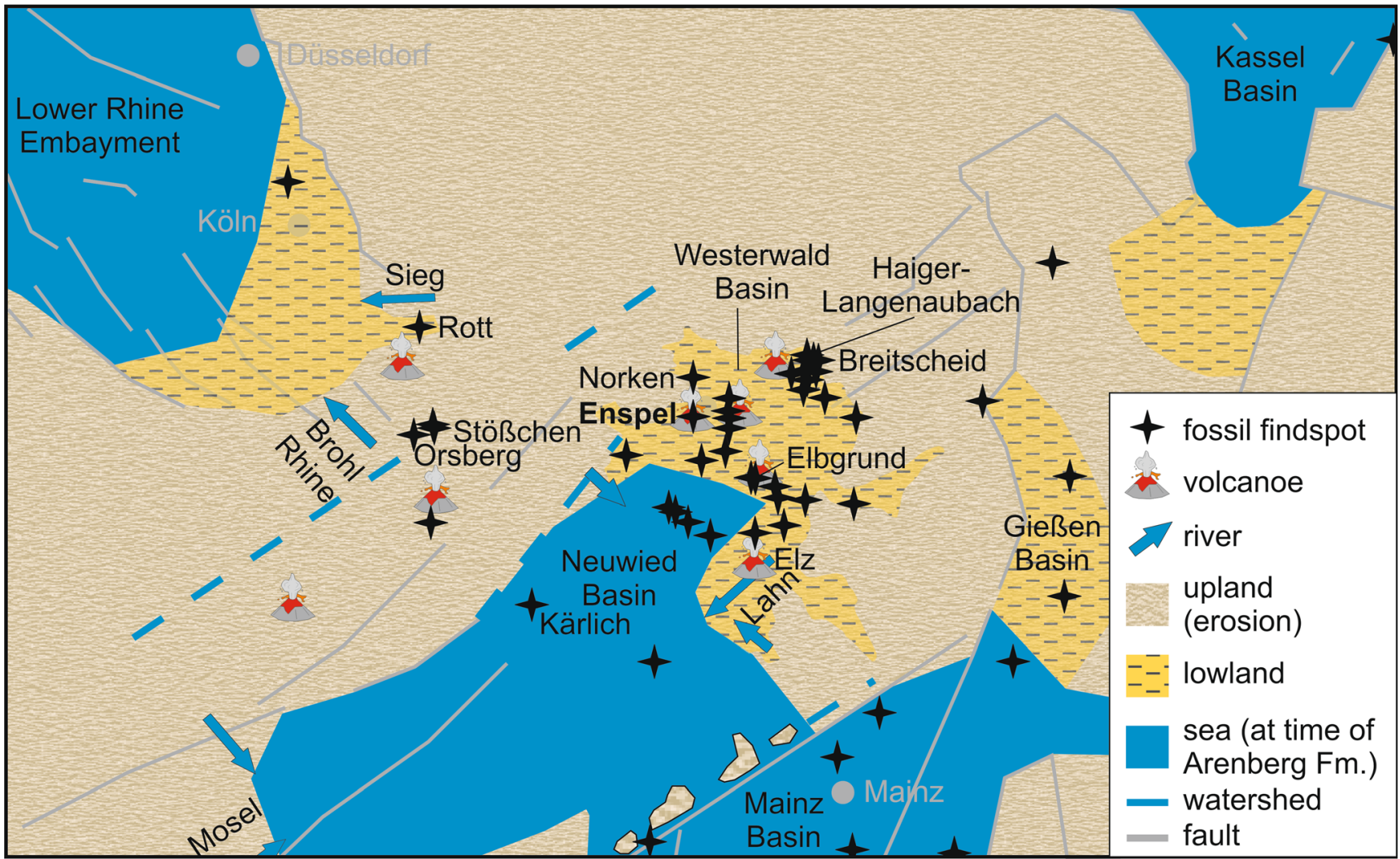

Fig. 1 Chattian palaeogeography of the Westerwald Basin (Arenberg, Breitscheid and Heckholzhausen Formation.) and neighbouring areas with fossil findspots and estimated watersheds (changed after Schindler and Wuttke 2013, fig. 1)

Resettlement of devastated landscapes by terrestrial fauna has not been investigated in detail thus far.

The intercalation of extrusives, some of which have been dated, with well-investigated fossil-bearing sediments allows for

- combining radiometric dating with biostratigraphy (as shown at the localities Enspel and Kärlich; Storch et al. 1996; Mörs 2002; Mertz et al. 2007; Steininger et al. 1997)

- investigation of ecosystem recovery in detail

- correlation of sea level in neighbouring marine basins with groundwater high stand in this terrestrial basin, as demonstrated for the Lower Rhine Embayment and the volcanicinfluenced lake of Rott (Mörs 1995)

- correlation of Westerwald fossil localities with the classic localities Orsberg and Stößchen (Felder et al. 2004)

Several scientific drillings (Lake Enspel 1996: Felder et al. 1998; Mertz et al. 2007; fossil site Elbgrund 2003: Felder et al. 2011; and Lake Norken 2009: Uhl et al. 2011), scientific excavations (Lake Enspel since 1990: Wuttke et al. 2010; Schindler and Wuttke 2015, this issue; fossil site Elbgrund 2004: Felder et al. 2011; and fossil site Haiger-Langenaubach 2008, 2009: Schindler and Kolb 2010) and well-documented outcrops (mainly clay pits) have yielded a dense sequence of well-correlated events documenting environmental change and biodiversity in this volcanically influenced basin (Schindler and Wuttke 2013).

The Enspel Formation, predominantly composed of laminated black pelites that richly document the evolution of the ancient crater lake Enspel, is a key locality for studies in this context. The first overview of the locality was given by Wuttke et al. (2010) and the contributors to that Special Issue of this journal. The present Special Issue now presents an enhanced sedimentological model, new palaeontological discoveries, and new insights into the palaeoecology and palaeoenvironment of this caldera and its catchment area.

1) Schindler and Wuttke present a detailled sedimentological model of Lake Enspel. Synchronous, episodic debris flows, caused by erosion on a high and unvegetated crater wall, play an important role throughout the duration of sedimentation. The levels of the lake water and groundwater and the altitudes of the surrounding landscape are reconstructed. (Palaeobio Palaeoenv 95(1). Doi:10.1007/s12549-014-0178-4)

2) Tütken and Absolon present stable carbon and oxygen isotope analyses of terrestrial and aquatic vertebrate fossils from Enspel $\delta^{18} \mathrm{O}$ of lake water, which ultimately derives from precipitation, is used to estimate mean 
annual air temperatures (MAT) in central Europe during the late Oligocene. These measurements are compared with those from coeval fossil sites in Switzerland. (Palaeobio Palaeoenv 95(1). Doi:10.1007/s12549-0140183-7)

3) Barden et al. present a major study of the so-called softpart preservation in Enspel tadpoles, which is relevant to the debate over whether autolithified bacteria or fossilized melanosomes are preserved in fossil vertebrates from Konservat-Fossillagerstätten. The authors chemically analysed the preserved micro-spheres in the skin shadow of a tadpole a variety of modern spectrometric techniques. (Palaeobio Palaeoenv 95(1). Doi:10.1007/ s12549-014-0177-5)

4) Uhl provides a preliminary overview of flowers and inflorescences from Enspel, fossils that have so far been neglected in palaeobotanical studies on this locality. He distinguishes different types of flowers and inflorescences of excellent morphological preservation, and contributes to a better understanding of the diversity of Enspel's palaeoflora and its palaeoenvironment. (Palaeobio Palaeoenv 95(1). Doi:10.1007/s12549014-0172-x)

5) Gunkel and Wappler investigate insect herbivory on leaves which is used to examine changes in insect damage with a high temporal resolution. In order to conduct robust analyses, they develop an extended mathematical framework for rarefaction that allows non-parametric comparisons of datasets and the detection of bias in collection effort. (Palaeobio Palaeoenv 95(1). Doi:10. 1007/s12549-014-0176-6)

6) Schoch et al. summarise recent knowledge about the late Paleogene to early Neogene salamander Chelotriton paradoxus and redescribe the species on the basis of new and excellent material from Enspel and from the Miocene Randeck Maar. Based on preliminary taphonomical data, the authors discuss the preferred habitat and the autecology of $C$. paradoxus. (Palaeobio Palaeoenv 95(1). Doi: 10.1007/s12549-014-0182-8)

7) Mayr describes a third cormorant specimen from Enspel. Its features allow the species to be returned provisionally to Oligocorax. A phylogenetic analysis revealed that ?O. stoeffelensis is more closely related to Phalacrocoracidae than to any other extant group, but its closeness to that clade relative to other fossil taxa remains uncertain. (Palaeobio Palaeoenv 95(1). Doi:10. 1007/s12549-014-0167-7)

8) Smith and Wuttke present an overview of the highly abundant ?owl pellets from Enspel. Rodents are the predominant prey item in the pellets, but a variety of other taxa are also present: actinopterygiian fish, anurans, and lizards. They suggest that prior dissication of these pellets on land may have allowed them to drift to the center of the lake. (Palaeobio Palaeoenv 95(1). Doi:10.1007/s12549-014-0179-3)

9) Mähler et al. explore a newly established branch of taphonomical research, the use of $\mu$-CTanalyses to provide a detailed, diachronic look into the decay under limnic conditions of the carcasses of small vertebrates. Applying this technique to the decomposition of extant Talpa europaea, together with other experiments, the authors were able to elucidate the taphonomic fate of a fossil mole from Lake Enspel. (Palaeobio Palaeoenv 95(1). Doi: 10.1007/s12549-014-0180-x)

10) Engler and Martin describe the first partial skeleton of a young adult Eomyodon volkeri. It shows a generalised rodent bauplan with an estimated body mass of about $10 \mathrm{~g}$. There are no indications of gliding adaptions, and a terrestrial lifestyle is assumed. (Palaeobio Palaeoenv 95(1). Doi: 10.1007/s12549-014-0174-8)

Acknowledgements The guest editors are grateful to the editors Peter Königshof and Sinje Weber for their disposition to publish a second special issue on the Fossillagerstätte Enspel and for their great contribution and enthusiasm in managing the editorial process.

\section{References}

Butz, R., Vortisch, W. (1987). Geological and clay-mineralogical investigations in the northeastern Westerwald. CFI; Berichte der Deutschen Keramischen Gesellschaft, (3/4), 97-103.

Felder, M., Gaupp, R., \& Wuttke, M. (2004). "Ölschie fer" der besonderen Art: die Süßwasserkarbonate der Grube Stößchen. Natur und Museum, 134, 77-84.

Felder, M., Radtke, G., \& Keller, T. (2011). Ein neues Schwarzpelitvorkommen im Westerwald (Forschungsbohrung Elbtal-Elbgrund, Hessen). Geologisches Jahrbuch Hessen, 137, 85-101.

Felder, M., Weidenfeller, M., \& Wuttke, M. (1998). Lithologische Beschreibung einer Forschungsbohrung im Zentrum des oberoligozänen, vulkano-lakustrinen Beckens von Enspel/ Westerwald (Rheinland-Pfalz; Bundesrepublik Deutschland). Mainzer Geowissenschaftliche Mitteilungen, 27, 101-136.

Haase, K. M., Goldschmidt, B., \& Garbe-Schönberg, C. D. (2004). Petrogenesis of Tertiary continental intra-plate lavas from the Westerwald Region, Germany. Journal of Petrology, 45(5), 883905.

Herrmann, M., Ashraf, A. R., Uhl, D., Mosbrugger, V. (2003). Eine palynologische Analyse der Bohrung Enspel, Rekonstruktion der Vegetations- und Klimageschichte im Oberoligozän: Erste Ergebnisse. Terra Nostra 2003(5) (73. Jahrestag. Paläont Ges 29.9.-3.10.2003, Abstr): 68.

Herrmann, M., Ashraf, A. R., Uhl, D., \& Mosbrugger, V. (2010). Die oberoligozäne Palynoflora der Bohrung Enspel 1996/1 (Westerwald, West-Deutschland) - Teil 2: Angiospermen und Paläoökologie. Mainzer Geowissenschaftliche Mitteilungen, 38, 9-60.

Hottenrott, M. (2002). Neue palynologische Daten zur stratigraphischen Einstufung der älteren Tonserie (Unteres Tonlager, Mittel-Eozän) im Westerwald. Courier Forschungsinstitut Senckenberg, 237, 69-75.

Köhler, J., \& Uhl, D. (2014). Die Blatt- und Karpoflora der oberoligozänen Fossillagerstätte Enspel (Westerwald, RheinlandPflaz, W-Deutschland). Mainzer naturwissenschaftliches Archiv, Beiheft, 35, 1-87. 
Mertz, D. F., Renne, P. R., Wuttke, M., \& Mödden, C. (2007). A numerically calibrated reference level (MP28) for the terrestrial mammal-based biozonation of the European Upper Oligocene. International Journal of Earth Science (Geologische Rundschau), 123, 353-361.

Mörs, T. (1995). Die Sedimentationsgeschichte der Fossillagerstätte Rott und ihre Alterseinstufung anhand neuer Säugetierfunde (Oberoligozän, Rheinland). Courier Forschungsinstitut Senckenberg, 187, 1-129.

Mörs, T. (2002). Biostratigraphy and paleoecology of continental Tertiary vertebrate faunas in the Lower Rhine Embayment (NW-Germany). Netherlands Journal Geosciences / Geologie en Mijnbouw, 81(2), 177-183.

Reischmann, T. (2011). Tertiärer Vulkanismus. - In: Grimm, K.I. (coord.), Stratigraphie von Deutschland IX, Tertiär, Teil 1: Oberrheingraben und benachbarte Gebiete; Schriftenreihe der Deutschen Gesellschaft für Geowissenschaften 75, 16-30.

Schäfer, P., Schindler, T., Hottenrott, M., Wuttke, M. (2011). Westerwald. - In: Grimm, K.I. (coord.), Stratigraphie von Deutschland IX, Tertiär, Teil 1: Oberrheingraben und benachbarte Gebiete; Schriftenreihe der Deutschen Gesellschaft für Geowissenschaften, 75, 355-375.

Schindler, T., Kolb, C. (2010). Paläontologische Notbergung in einer Tongrube im Lahn-Dill-Kreis. Pflanzen, Fische und Kaulquappen aus tertiären Vulkanablagerungen. hessenARCHÄOLOGIE 2009, 19-29.

Schindler, T., Wuttke, M. (2013). Volcanically influenced terrestrial ecosystems of the Westerwald Basin (Upper Oligocene, $W$ Germany). Basalt2013 Cenozoic Magmatism in Central Europe, 24th to 28th April 2013, Görlitz, Germany: 150-151.
Schindler, T., Wuttke, M. (2015). A revised sedimentological model for the Late Oligocene Lake Enspel (Enspel Formation, Westerwald Mountains, Germany). In: Wuttke M, Schindler T, Smith KT (eds) The Fossil-Lagerstätte Enspel - reconstructing the palaeoenvironment with new data on fossils and geology. Palaeobiodiversity Palaeoenvironments 95(1) doi:10.1007/ s12549-014-0178-4.

Schreiber, U. (1996). Tertiärer Vulkanismus des Westerwaldes. In: Schäfer A, Thein J (eds): Exkursionsführer. Geologische Stoffkreisläufe und ihre Veränderungen durch den Menschen. Terra Nostra 1996(7):187-212.

Steininger, F. F., Aubry, M. P., Berggren, W. A., Biolzi, M., Borsetti, A. M., Cartlidge, J. E., Cati, F., Corfield, R., Gelati, R., Iaccarino, S., Napoleone, C., Ottner, F., Ro, G. L. F., Roetzel, R., Spezzaferri, S., Tateo, F., Villa, G., \& Zevenboom, D. (1997). The global stratotype section and point (GSSP) for the base of the Neogene. Episodes, 201, 23-28.

Storch, G., Engesser, B., \& Wuttke, M. (1996). Oldest fossil record of gliding in rodents. Nature, 379(1), 439-441.

Teike, M., Tobien, H, (1950). Über Säugerreste aus der Braunkohlengrube "Glückauf-Phönix" bei Breitscheid/Westerwald. Notizblatt des Hessischen Landesamtes für Bodenforschung zu Wiesbaden, (VI), $112-119$.

Uhl, D., Schindler, T., \& Wuttke, M. (2011). Paläoökologische Untersuchungen im Oberoligozän von Norken (Westerwald, Rheinland-Pfalz, W-Deutschland) - Erste Ergebnisse. Mainzer Naturwissenschaftliches Archiv, 48, 115-127.

Wuttke, M., Uhl, D., \& Schindler, T. (2010). The Fossil-Lagerstätte Enspel - exceptional preservation in an Upper Oligocene maar. Palaeobiodiversity and Palaeoenvironments, 90, 1-98. 